\title{
Article \\ Weevil Borers Affect the Spatio-Temporal Dynamics of Banana Fusarium Wilt
}

\author{
Daniel W. Heck (D), Gabriel Alves and Eduardo S. G. Mizubuti *(D) \\ Departamento de Fitopatologia, Universidade Federal de Viçosa, Viçosa 36570-900, Minas Gerais, Brazil; \\ dwinterheck@gmail.com (D.W.H.); gabriel.alves2@ufv.br (G.A.) \\ * Correspondence: mizubuti@ufv.br
}

check for updates

Citation: Heck, D.W.; Alves, G.; Mizubuti, E.S.G. Weevil Borers Affect the Spatio-Temporal Dynamics of Banana Fusarium Wilt. J. Fungi 2021, 7, 329. https://doi.org/10.3390/ jof7050329

Academic Editors: Guy Blomme, George Mahuku and Miguel Dita

Received: 1 April 2021

Accepted: 22 April 2021

Published: 24 April 2021

Publisher's Note: MDPI stays neutral with regard to jurisdictional claims in published maps and institutional affiliations.

Copyright: (c) 2021 by the authors. Licensee MDPI, Basel, Switzerland. This article is an open access article distributed under the terms and conditions of the Creative Commons Attribution (CC BY) license (https:/ / creativecommons.org/licenses/by/ $4.0 /)$.

\begin{abstract}
Dispersal of propagules of a pathogen has remarkable effects on the development of epidemics. Previous studies suggested that insect pests play a role in the development of Fusarium wilt (FW) epidemics in banana fields. We provided complementary evidence for the involvement of two insect pests of banana, the weevil borer (Cosmopolites sordidus L., WB) and the false weevil borer (Metamasius hemipterus L., FWB), in the dispersal of Fusarium oxysporum f. sp. cubense (Foc) using a comparative epidemiology approach under field conditions. Two banana plots located in a field with historical records of FW epidemics were used; one was managed with Beauveria bassiana to reduce the population of weevils, and the other was left without $B$. bassiana applications. The number of WB and FWB was monitored biweekly and the FW incidence was quantified bimonthly during two years. The population of WB and the incidence $(6.7 \%)$ of $\mathrm{FW}$ in the plot managed with B. bassiana were lower than in the plot left unmanaged (13\%). The monomolecular model best fitted the FW disease progress data, and as expected, the average estimated disease progress rate was lower in the plot managed with the entomopathogenic fungus $(r=0.002)$ compared to the unmanaged plot $(r=0.006)$. Aggregation of FW was higher in the field with WB management. WB affected the spatial and temporal dynamics of FW epidemics under field conditions. Management of the insects may reduce yield loss due to FW.
\end{abstract}

Keywords: Fusarium oxysporum f. sp. cubense; Panama disease; spatio-temporal dynamic; Cosmopolites sordidus; Metamasius hemipterus

\section{Introduction}

Understanding the ways a pathogen is dispersed is one of the most important tasks in the epidemiology of plant diseases. For Fusarium wilt (FW) of bananas, caused by Fusarium oxysporum f. sp. cubense (Foc) (E. F. Smith) Snyder and Hansen, there is limited information about the mechanism of pathogen dispersal. It is suggested that Foc can be dispersed mainly by human influence, such as exchange of asymptomatic propagation material, cultural practices performed with infested tools or conducted by untrained workers, and movement of soil particles adhered to boots, machinery, and tires of vehicles [1,2]. Good management practices, sterilization of materials, and appropriate training of plantation workers can greatly reduce dispersal and the likelihood of pathogen introduction in areas without records of FW.

Even under conditions of proper management practices, severe epidemics can occur. Natural dispersal agents or processes such as wind, water, and animals, including mammals and insects, are more difficult to detect and control. Some reviews highlighted the potential of these dispersal processes in the movement of Foc propagules at short or long distances [1-4]. Surface water and rivers infested with Foc propagules were suggested as the cause of the rapid spread of FW epidemics in China, Malaysia, and the Philippines [2,5]. F. oxysporum does not move long distances in soil. It is expected that local pathogen dispersal occurs when the pathogen colonizes roots of susceptible hosts or is passively transported in soil particles by animals, wind, and water. Inoculation normally occurs 
when root growth contacts the inoculum distributed in the soil or by root-to-root contact [6]. Eventually, Foc may be dispersed aerially. The presence of sporodochia and hyphal growth externally in plant tissues suggest aerial dispersal of Foc [7].

Any animal or material that can carry soil particles in banana fields is a potential dispersal agent of Foc. The free circulation of animals such as feral pigs in banana fields was cited as a potential mechanism of dispersal of Foc [8]. The potential role played by the banana weevil borer (Cosmopolites sordidus L., Coleoptera: Curculionidae), referred to here as weevil borer (WB), in special, was suggested to be responsible for the inoculation of isolated banana plants in the field [9]. Inoculum of Foc was reported in the external and internal body parts of $\mathrm{WB}$, and the pathogen propagules remained viable for up to three days [10]. The weevil borer is the main insect pest in banana fields and can occur in large populations [11]. Other pests, such as the West Indian sugarcane weevil (Metamasius hemipterus L., Coleoptera: Curculionidae), referred to as false weevil borer (FWB) by banana growers, are important pests in sugarcane and other crops. The FWB is also observed causing damages in plantain fields under high populations [12]. The management of the weevils in banana fields is primarily based on the application of insecticides $[13,14]$. However, the weevils' ability to develop resistance against a broad range of chemicals makes integrated pest management, which includes host-plant resistance, cultural methods, and biological control, the most reasonable option [11]. Curculionidae members acting as vectors of plant diseases are commonly reported in many crops. M. hemipterus and Rhynchophorus palmarum (Coleoptera: Curculionidae) were suspected to be vectors of the nematode Bursaphelenchus cocophilus (=Rhadinaphelenchus cocophilus), the causal agent of red ring disease in oil palm $[15,16]$. R. palmarum was also reported as a dispersal agent of bud rot disease (Phytophthora palmivora) in oil palm [17] and stem bleeding (Thielaviopsis paradoxa) in coconut palm [18].

Since the study carried out by Meldrum et al. [9], the effective contribution of the banana weevil in the FW epidemics under field conditions remains unanswered. Nevertheless, these answers may be useful to the development of preventive measures against quarantine pathogens, such as Foc Tropical Race 4 (TR4), and effective management strategies to control the expansion of FW foci within the fields. The objective of this study was to understand the relationship of two potential vectors of Foc, C. sordidus, and M. hemipterus in the FW epidemics using a comparative epidemiology approach: a spatio-temporal study under field conditions.

\section{Materials and Methods}

\subsection{Field}

One banana field where FW was known to have occurred was selected to study the association between insect pests and FW epidemics. The field was located in the municipality of Teixeiras, Minas Gerais state, Brazil, cultivated with Prata-type banana (Pome subgroup, AAB). The field was managed as a low-input system with plants spaced approximately $3 \mathrm{~m} \times 5 \mathrm{~m}$ within and between rows, respectively. Irrigation, fertilization, and cultural practices such as removal of suckers and pest or disease control had not been adopted.

The field was subdivided into two plots. In one plot $\left(20^{\circ} 38^{\prime} 21.444^{\prime \prime} \mathrm{S} ; 42^{\circ} 50^{\prime} 1.752^{\prime \prime} \mathrm{W}\right.$ and 772 masl) of $1.03 \mathrm{ha}$, low population of WB was attempted by means of one initial application of a chemical insecticide followed by several applications of a biological control agent. In the second plot $\left(20^{\circ} 38^{\prime} 19.5^{\prime \prime} \mathrm{S} ; 42^{\circ} 50^{\prime} 2.544^{\prime \prime} \mathrm{W}\right.$ and 759 masl) of 1.2 ha, no control practices for WB and FWB were adopted. The management of insects was conducted every three months. Carbofuran (Furadan $50 \mathrm{G}^{\circledR}$, FMC Corporation, Uberaba, Brazil) was applied at $3 \mathrm{~g}$ of commercial product per cheese trap. Cheese traps were made by cross-cutting pseudostems of harvested plants approximately $40 \mathrm{~cm}$ high from the soil. The insecticide was applied on the cut surface of the lower section (lower half) of the trap, and then the upper section was placed back on top of the treated half. Forty cheese traps were utilized per ha at the beginning of the experiment. The first application with 
chemical insecticide was used to substantially reduce the population of weevils in the managed plot only. Due to regulatory issues, carbofuran was restricted in Brazil just after the application in the experimental area and subsequent management practices to control insects were performed with a commercial formulation of the entomopathogenic fungus Beauveria bassiana (Ballvéria WP ${ }^{\circledR}$, Ballagro, Bom Jesus dos Perdões, Brazil; and Beauveria Oligos WP ${ }^{\circledR}$, Oligos Biotec, São José do Rio Preto, Brazil) applied every three months at a rate of $5 \mathrm{~g}$ per trap and 30 to 40 traps per ha. The biological product was applied via the cheese traps as described for the chemical insecticide.

From April 2017 to February 2019, the study period, the average temperature was $19.4{ }^{\circ} \mathrm{C}$ with a minimum of $5.5^{\circ} \mathrm{C}$ and a maximum of $35.3^{\circ} \mathrm{C}$. The average relative humidity was $76.6 \%$ and the accumulated total precipitation was $2069 \mathrm{~mm}$. The hourly meteorological data were obtained from a climate station located at $14.4 \mathrm{~km}$ from the field and were provided by Instituto Nacional de Meteorologia (INMET) of Ministério da Agricultura, Pecuária e Abastecimento (MAPA).

\subsection{Insects Monitoring}

The second type of pseudostems trap, the roof-tile trap, was used to monitor the WB and FWB populations. Pseudostems of harvested plants were cross-cut in sections of $30 \mathrm{~cm}$ length and subsequently lengthwise in half such as to produce two hemicylindrical traps. The sections were placed with the cut side down (in contact with soil). Fifteen roof-tile traps per plot were made and placed approximately $15 \mathrm{~cm}$ apart from the banana mat. The traps were randomly distributed in the plots and maintained in the same place throughout the experiment. Monitoring was performed from May 2017 to February 2019. Traps were evaluated by counting the number of WB and FWB every two weeks and replacing old traps with new ones. Data were analyzed by ANOVA for repeated measures followed by a pairwise $t$-test comparison of the effects of management on each assessment time with the RSTATIX package [19].

In addition to the chemical and biological control methods, insects collected in the monitoring traps were eliminated. The chemical, biological, and physical removal of the insects were performed on the managed plot only.

\subsection{Fusarium Wilt Assessment}

Banana plants were visually assessed for external and internal symptoms of FW. If external symptoms such as wilt, yellowing, and collapse of older leaves, and/or splitting at the base of pseudostem in at least one plant of the mat was observed, a small cut was made in the pseudostem to inspect for internal symptoms. Internally, diseased plants presented yellow, reddish-brown, or black discolorations of vascular tissues. If external and internal symptoms were present, the mat was considered diseased and was georeferenced using a handheld GPS device (GPSMAP ${ }^{\circledR}$ 64, Garmin, Lenexa, United States). The diseased banana mat was identified with striped plastic tape to avoid double quantification in future assessments. GPS files with the geographic location of diseased plants and polygons were extracted and converted to text files and imported in R Statistical Software version 3.5.1 [20]. Fragments ( $n=10 ; 5 \mathrm{~cm}$ of length $\times 5 \mathrm{~cm}$ of width) of pseudostems taken from symptomatic plants from the field were used to isolate the pathogen and confirm the presence of Foc by morphological [21] and molecular methods [22]. The plots were assessed from April 2017 to February 2019 every two months, resulting in 12 assessments.

\subsection{Spatio-Temporal Analyses}

\subsubsection{Temporal analysis}

The area size, centroid, and the total number of plants in each plot were estimated using the polygon data set and the plant spacing information (distance within and between rows). The diseased plant data set was used to estimate the total number and location of diseased plants $(x)$ in plots at each assessment. The incidence $(p)$ was calculated as $p=\Sigma x / \Sigma n$, where $x$ was the number of diseased plants and $n$ the estimated total number 
of plants (healthy and diseased) on each plot. The incidence was calculated at each assessment date. The Monomolecular, Logistic, and Gompertz models were fit to the disease incidence data plotted over time by nonlinear regressions using the $n l s L M$ function from MINPACK.LM package [23]. The choice of the best model was performed by the linear mixed-effects model [24] using the LME function from the NLME package [25].

\subsubsection{Spatial Analyses}

Two types of spatial analyses were conducted: a point-pattern and a geostatisticalbased approach. Field maps with the geolocation of diseased plants were quadratized using the QUADRATCOUNT function of the SPATSTAT package [26]. The quadrat size used was $2 \times 2$, i.e., the area occupied by two plants within and between rows, respectively. The number of diseased plants in each quadrat was determined and used to perform the spatial analysis. The exact number of plants inside each quadrat could not be computed because the distance within and between rows was irregular. The estimated precision of the GPS device varied between 3 and $7 \mathrm{~m}$ during the assessments depending on the environmental conditions.

Dispersion index for binomial data, $\mathrm{D}$, referred to sometimes as the ratio between variances, was used for the point-pattern approach. A $\chi^{2}$ test was performed to test the null hypothesis of dispersion index $(D)=1$. The analysis was conducted using the AGG_INDEX function from the EPIPHY package [27]. Spatial Analysis by Distance IndicEs (SADIE) was the method chosen in the geostatistical-based approach. SADIE uses the location of the sampling units (i.e., quadrats) and the number of individuals (i.e., diseased plants) inside the unit to analyze the spatial arrangement by the distance to regularity $\left(D_{r}\right)$ criterion. The $D_{r}$ is achieved when all the sampling units have the same number of diseased individuals. SADIE returns an overall aggregation index $\left(\mathrm{I}_{\mathrm{a}}\right)$ which reflects the ratio between the distance moved to achieve a regular pattern for the observed data and a theoretical mean to regularity based on random permutations. The index developed by Li et al. [28] was computed by the SADIE function from the EPIPHY package [27]. A random pattern was inferred when the D and SADIE aggregation indices were equal to 1 , an aggregated pattern when they were higher than 1 , and regular when less than 1 .

\subsubsection{Spatio-Temporal Study}

The relationship between the observed and theoretical variances of FW incidence per sampling unit over time was evaluated. The equation for a binary power law, $\log _{10}\left(s^{2}\right)=\log _{10}(A)+b \cdot \log _{10}\left(s^{2}\right.$ bin $)$, where $s^{2}$ is the observed variance, $s^{2}$ bin the theoretical variance assuming a binomial distribution, and $A$ and $b$ are the parameters to be estimated. Estimates of $A=b=1$ suggest a random distribution; if $A>1$ and $b=1$ suggest an aggregated pattern with fixed value independently of the incidence level; and if both parameters, $A$ and $b>1$, the level of aggregation varies with incidence [29]. A $t$-test was performed to test the null hypothesis for individual plots and to test if the parameters differed between the plots.

\section{Results}

Management and monitoring of WB were successfully carried out from April 2017 to February 2019. A significant interaction between assessment time and management of WB was observed (Table 1). The number of WB was lower in the plot managed with B. bassiana (median of 0.67 per trap) when compared to the unmanaged field (1.6 per trap) in $37 \%$ (17 of 46) assessments ( $p<0.001$; Table 1; Figure 1a). Weevil borer population was higher in the managed plot in the first assessment only, prior to the application of insecticide (Figure 1a). Management with B. bassiana did not affect the population of FWB in the same period ( $p=0.723$; Table 1; Figure 1b). Notwithstanding, the interaction with time was observed (Table 1). Significant differences between managed and unmanaged plots were observed in $22 \%$ (10 of 46 ) of the assessments. The population of WB was significantly higher in the managed plot in five of ten assessments (Figure 1b). 
Table 1. Summary of analysis of variance for repeated measures of weevil borer (Cosmopolites sordidus, WB) and false weevil borer (Metamasius hemipterus, FWB) populations between managed and unmanaged plots located in the municipality of Teixeiras, Minas Gerais state, Brazil, assessed from April 2017 to February 2019.

\begin{tabular}{ccccccc}
\hline \multirow{2}{*}{ Effect } & \multicolumn{3}{c}{ Cosmopolites sordidus } & \multicolumn{3}{c}{ Metamasius hemipterus } \\
\cline { 2 - 7 } & $\mathbf{d f}$ & $\boldsymbol{F}$ & $\boldsymbol{p}$ & $\mathbf{d f}$ & $\boldsymbol{F}$ & $\boldsymbol{p}$ \\
\hline Management & 1 & 42.24 & $<0.001$ & 1 & 0.13 & 0.723 \\
Time & 45 & 10.10 & $<0.001$ & 45 & 12.12 & $<0.001$ \\
Management:Time & 45 & 3.69 & $<0.001$ & 45 & 3.33 & $<0.001$ \\
\hline
\end{tabular}
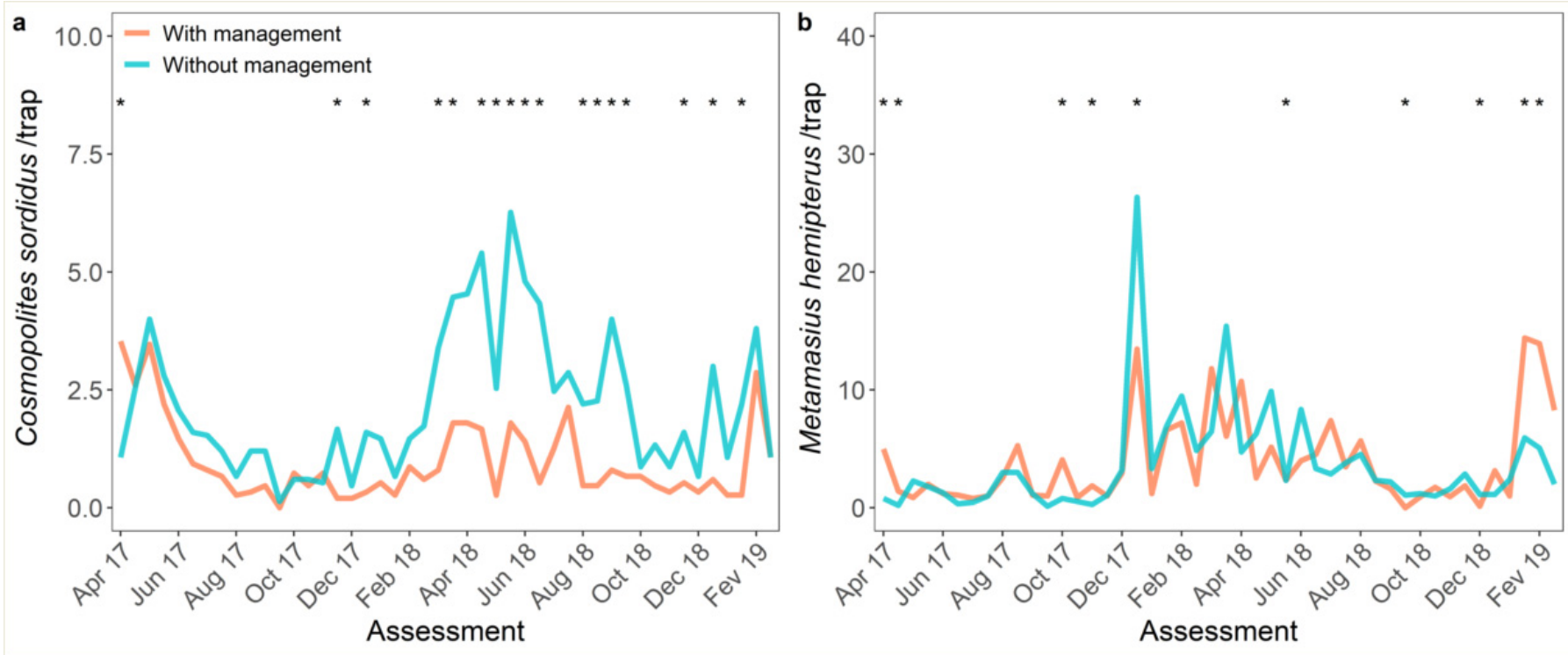

Figure 1. Biweekly monitoring of: (a) weevil borer (Cosmopolites sordidus, WB) and (b) false weevil borer (Metamasius hemipterus, FWB) in plots with and without control of WB, from April 2017 to February 2019. Significant differences $(p<0.05)$ by pairwise $t$-test comparison of the effects of management at a given assessment time are represented by an asterisk.

Fusarium wilt incidence was lowest in the first assessment: $0.9 \%$ and $2 \%$ in the plots with and without WB management, respectively (Figure 2). These two plots already had diseased plants when the assessments began. After 12 assessments, disease incidence in these two plots reached up to $6.7 \%$ and $13 \%$ in fields with and without WB management, respectively (Figure 2). The monomolecular model described the disease progress in both plots (Table 2). Significant differences were not observed for the initial incidence parameter ( $p=0.135)$ between the plots, and the disease progress rate was significantly higher in the unmanaged plot $(p<0.001$; Figure 2$)$.

Spatial analyses were computed for both fields using point-pattern and geostatisticalbased approaches. Aggregation of FW epidemics was inferred in all assessments and both plots by the dispersion index (Figure 3a). Aggregation was lowest in the first two assessments and highest in the last. Aggregation was also higher in the plot with WB management than in the unmanaged field $(p<0.001)$. The dispersion index ranged from 1.90 to 2.47 with a mean of 2.23 in the managed plot and from 1.34 to 2.27 with a mean of 1.86 in the unmanaged (Figure 3a). 


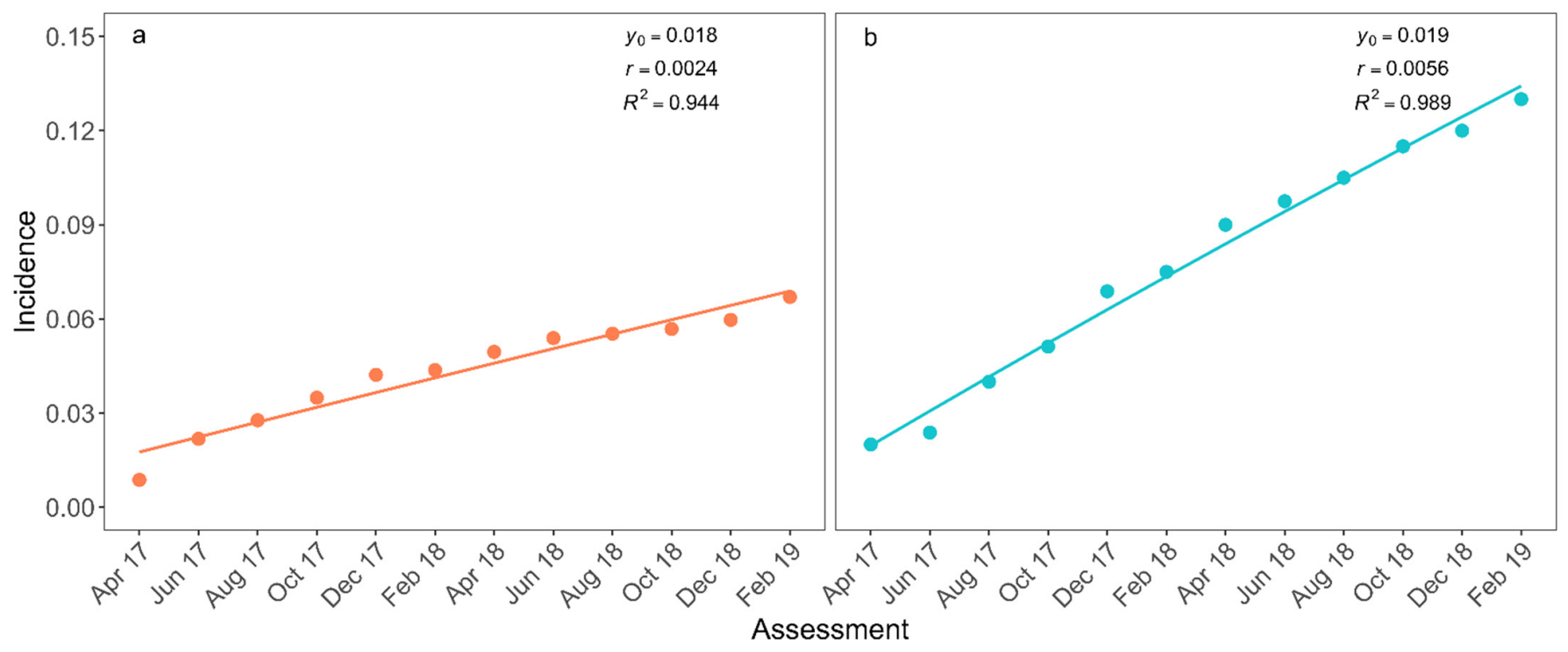

Figure 2. Incidence of Fusarium wilt of bananas in plots with (a) and without (b) management of weevil borer (Cosmopolites sordidus, WB) from April 2017 to February 2019 (points). Monomolecular model adjusted to incidence data (curves) Estimated initial incidence $\left(y_{0}\right)$, progress rate $(r)$ of epidemics, and the measure of the quality of the adjusted monomolecular model $\left(R^{2}\right)$ are presented.

Table 2. Summary of statistics used to evaluate the disease progress curve of Fusarium wilt of banana in two plots, with and without weevil borer management, located in the municipality of Teixeiras, Minas Gerais state, Brazil, from April 2017 to February 2019.

\begin{tabular}{|c|c|c|c|c|}
\hline Model & $\operatorname{AIC}^{a}$ & BIC $^{b}$ & logLikelihood & Best Adjust $/ n$ \\
\hline Monomolecular & -219.95 & -213.98 & 115.98 & $2 / 2$ \\
\hline Logistic & -137.39 & -131.41 & 74.69 & $0 / 2$ \\
\hline Gompertz & -153.44 & -147.47 & 82.72 & $0 / 2$ \\
\hline
\end{tabular}

a AIC, Akaike Information Criterion; ${ }^{\mathrm{b}}$ BIC, Bayesian Information Criterion.
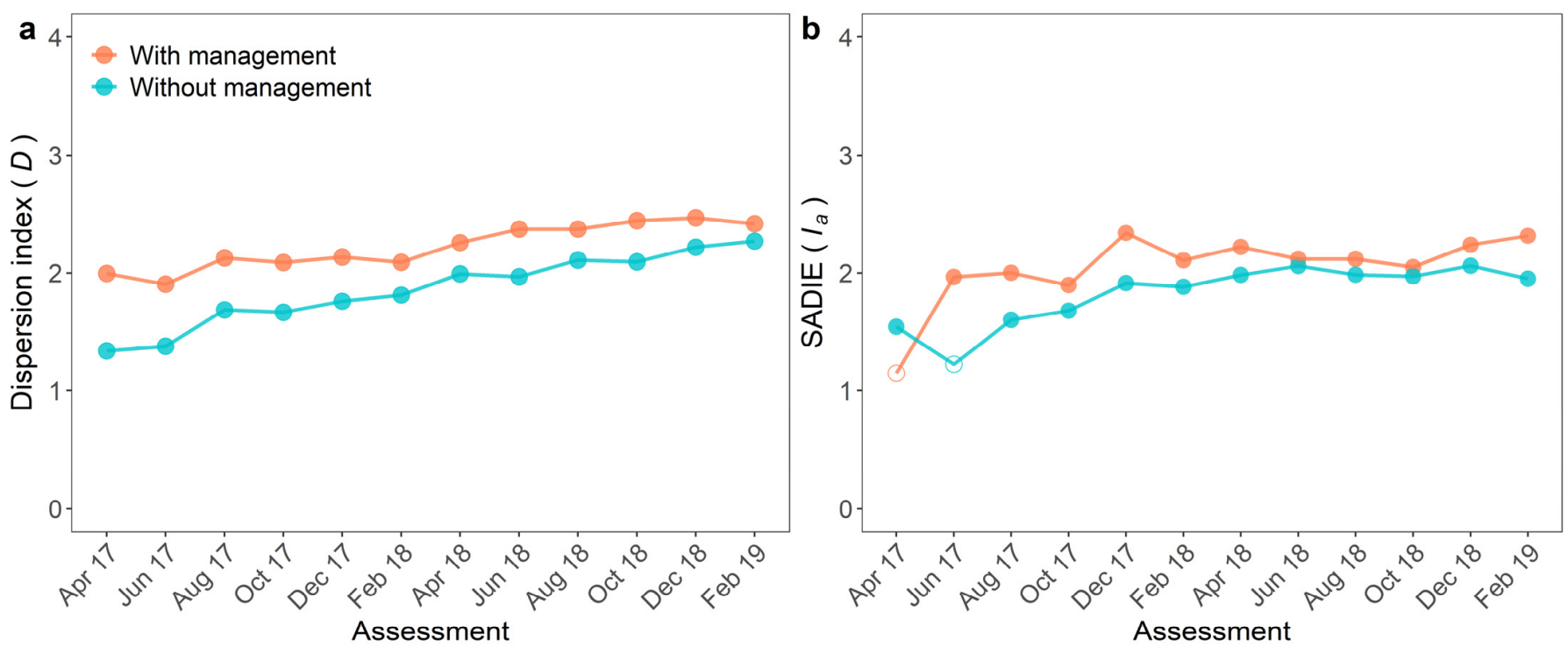

Figure 3. (a) Dispersion index $(D)$ and (b) aggregation index $\left(I_{a}\right)$ of Spatial Analysis by Distance Indices (SADIE) of incidence of Fusarium wilt of banana in two plots, with and without management of weevil borer (Cosmopolites sordidus, WB), from April 2017 to February 2019. Significant $(p<0.05)$ and non-significant $(p>0.05)$ values are represented by filled or empty circles, respectively, in the plot under a given management system, at a given date. When $p<0.05$, the spatial pattern was considered aggregated. 
The random pattern was detected using SADIE in the first assessment only in the plot with management and in the second assessment, in the plot without management (Figure 3). In these assessments, the $I_{a}$ values were low (1.15 and 1.23) (Figure 3b). The highest $I_{a}$ value (2.34) was observed in the managed plot. The degree of aggregation obtained by SADIE differed between the plots. The $I_{a}$ was higher in the managed (median of 2.04) compared to the unmanaged plot (1.82) ( $p=0.016$; Figure $3 b)$.

Binary power law expresses the relationship between the logarithm of the observed variance and the logarithm of theoretical variance assuming a binomial distribution and was well adjusted in plots with $\left(R^{2}=0.992\right)$ and without $\left(R^{2}=0.998\right)$ WB management (Figure 4). Parameters of the binary power law, $A$ and $b$, were higher than $1(p<0.001)$ for both plots. The level of aggregation in plots varied according to the incidence observed. The $A$ and $b$ parameters also differed between plots $(p<0.001)$. The aggregation in the unmanaged plot was more affected by the changes in incidence than in the managed plot (Figure 4).

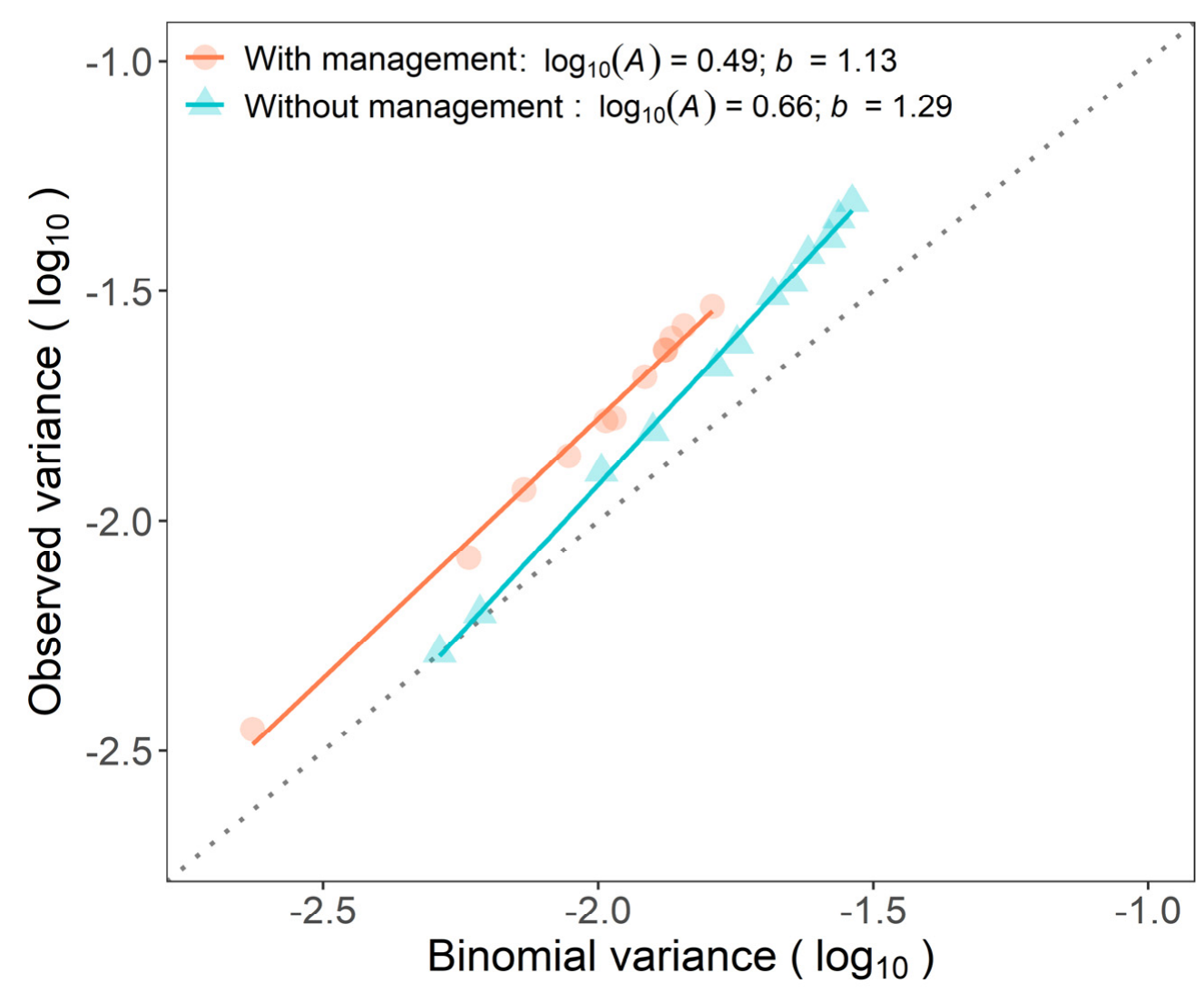

Figure 4. Binary power law of successive assessments for incidence of Fusarium wilt of banana from April 2017 to February 2019 in two plots, with and without management of weevil borer (Cosmopolites sordidus, WB).

\section{Discussion}

Currently, there is high interest in the dispersal mechanisms of Foc [1,2]. This information is crucial for the management of FW in already-infested areas as well as for setting exclusion and mitigation actions in disease-free fields. The role played by pests that are present in banana fields still needs to be elucidated. Epidemiological information can be useful to develop management strategies to effectively reduce the spread of Foc and reduce the damage caused by FW. In this study, the spatio-temporal approach was used to try to shed light on the putative role played by insect vectors on epidemics of FW.

The management of banana weevil was performed using B. bassiana, an entomopathogenic fungus widely used to control banana weevils and false weevils [30-34]. The 
entomopathogen enters the insect through the spiracles, digestive system, or insect cuticle and grows in hemocoel and muscle tissues, destroying tracheal taenidia and fat bodies [30]. B. bassiana reduced the population of WB by $40 \%$ after one year of application under field conditions [31]. In our study, the WB population was reduced, on average, by $58 \%$ after two years of $B$. bassiana application. In both plots, the population of FWB was higher than that of WB. False weevil borer is considered a secondary pest in banana and other crops [12]. However, in high populations, it damages plantain plantations and management needs to be considered [12]. In this study, the population of M. hemipterus was not affected by B. bassiana, even though many dead individuals were constantly found in traps. FWB has the ability to fly, giving it higher mobility compared to the WB in the fields. In addition, an abandoned banana plantation close to the managed plot probably masked the counts of FWB. These facts could have increased the chances of FWB being attracted to the pseudostems traps [35].

Differences in the disease-progress curve of FW incidence were observed between the two plots. The incidence was lowest in the first assessment and increased over time, reaching $13 \%$ in the unmanaged and $6.7 \%$ in the managed plot. These values can be considered low when compared to reports in Tanzania and Indonesia where the FW incidence reached $77 \%$ and $100 \%$, respectively $[36,37]$. However, the cultivars, environmental conditions, cultural practices, and the stage on which the epidemic was assessed could affect the incidence values observed. The plots studied were cultivated with a Prata-type cultivar (Pome subgroup, $\mathrm{AAB}$ ) that has intermediate resistance to race 1 of the pathogen [1]. Intermediate resistance contributes to reducing the disease progress rate and is one of the main strategies in controlling epidemics [38]. The progress of FW was best described by the monomolecular model. Differences between the initial incidences were not detected and the disease rate was higher in the plot with the highest WB population. This fact indicated that the dynamics of FW epidemics may have been affected by the insect population, probably acting as a dispersal agent or predisposing the banana plants to infection by Foc [9].

Aggregation was the prevalent pattern in both fields during the study. A higher degree of aggregation was observed in the plot with lower populations of WB. Higher spatial heterogeneity was observed in the managed plot compared to the plot left unmanaged. A higher degree of aggregation could be due to plant-to-plant transmission. A diseased plant acts as an inoculum source to the nearest neighbor plants. Root-to-root was the main transmission mechanism of F. oxysporum f. sp. radicis-lycopersici in tomato fields [6]. Aggregation was also the dominant pattern detected by the geostatistical-based method, SADIE. The clusters of diseased plants were closer in WB-managed plots than in the unmanaged. Additionally, the degree of aggregation according to both methods, $D$ and $I_{a}$, increased over time, showing higher values in the last assessments. Initial infections of stem bleeding disease of coconut palm had a random pattern in the first assessments but evolved to an aggregated pattern in the last [39].

At low levels of incidence, the plot managed for WB presented higher aggregation of FW. The level of aggregation was directly related to disease incidence in the plot without management. Reducing the population of a vector with management, the pathogen dispersal at greater distances is reduced and dispersal occurs more at neighboring plants. In the unmanaged plot, the disease was more randomly distributed over time, with new foci appearing far from the initial ones. This may be interpreted as evidence of WB acting as a within-field vector. However, no inference can be made regarding vectoring the pathogen among neighboring banana fields.

The spatio-temporal dynamic of FW epidemics may also be impacted by the differential behavior of WB and FWB. C. sordidus adults have limited mobility. Even though they have functional wings, flight is rare, and movement by crawling is limited, and they are attracted by host volatiles [11]. Unpublished studies performed in Uganda demonstrated that $81 \%$ of the $C$. sordidus released moved only up to $15 \mathrm{~m}$ during a six months' time period [11]. Only 3\% of the individuals moved farther than $25 \mathrm{~m} \mathrm{[11].} \mathrm{On} \mathrm{the} \mathrm{other} \mathrm{hand,}$ 
M. hemipterus is more active and mobile. M. hemipterus are good flying insects and are attracted by wounds and plant debris but can also feed on banana plants [12,40].

Although WB had limited movement, differences in spatial patterns were detected between the two fields studied and could bring new insights about the contribution of the pest in FW epidemics. F. oxysporum f. sp. cubense is a soilborne pathogen and due to the crawling habit of WB [11], soil particles can easily be found in their exoskeleton. On the other hand, FWB is a good flier, and it is possible that movement in soil is more limited than WB [40]. Notwithstanding, it is expected that WB, at the individual level, had a higher potential to carry Fusarium propagules than FWB. It is also hypothesized that WB larvae have a preference to feed on rhizomes [11] of banana plants, while larvae of FWB prefer to feed on stems or plant debris [12,40]. Further studies need to account for these differences in the behavior of the vector to fully understand the contributions of M. hemipterus in FW epidemics and to test these hypotheses.

Approximately ten percent of the WB collected in fields with FW epidemics were identified carrying viable spores of Foc TR4 in their exoskeleton [9]. The maximal inoculum acquisition by WB adults occurred after one hour of contact with infected pseudostems [10]. In the environment, the contact between insects and inoculum sources, as infested soil or Foc-infected banana tissues, can be longer but may not impact the concentration of inoculum in their bodies. Additionally of great importance is the time between acquisition and inoculation of healthy plants. Foc propagules remained viable for approximately three days, but viability dropped exponentially after acquisition [10]. If the infested insect does not move to new banana mats in three days [10] and if the pathogen is not endemic or widely spread in the area, the chances of Foc being inoculated into healthy plants are drastically reduced.

The contribution of WB in the spatio-temporal dynamic of FW epidemics under field conditions was highlighted in this study. Fields with lower WB populations presented a more aggregated pattern, demonstrating that the dispersal of Foc at greater distances was minimized. These results may direct new studies to clarify the interaction between Foc and their potential vectors. In addition, direct management practices, such as rigorous $\mathrm{WB}$ control, can reduce the impact of FW epidemics. Better management of banana FW relies on the development of efficient strategies to reduce the dispersal of Foc within and between fields.

Author Contributions: Conceptualization, D.W.H. and E.S.G.M.; methodology, D.W.H., G.A., and E.S.G.M.; investigation, D.W.H. and G.A.; formal analysis, D.W.H.; data curation, D.W.H. and E.S.G.M.; writing — original draft preparation, D.W.H.; writing—review and editing, D.W.H., G.A., and E.S.G.M. All authors have read and agreed to the published version of the manuscript.

Funding: This study was financed in part by the Coordenação de Aperfeiçoamento de Pessoal de Nível Superior-Brasil (CAPES)—Finance Code 001.

Institutional Review Board Statement: Not applicable.

Informed Consent Statement: Not applicable.

Data Availability Statement: The data presented in this study are available on request from the corresponding author. The data are not publicly available due to restrictions.

Acknowledgments: The authors are grateful to Luis Carlos Costa for his help in disease assessments and weevils monitoring and to the grower Josimar Ribas for allowing two years of experiments on his banana field. All authors are grateful to the Conselho Nacional de Pesquisa Científica (CNPq) for the fellowships - 141026/2015-4.

Conflicts of Interest: The authors declare no conflict of interest. 


\section{References}

1. Dita, M.; Barquero, M.; Heck, D.; Mizubuti, E.S.G.; Staver, C.P. Fusarium Wilt of Banana: Current Knowledge on Epidemiology and Research Needs toward Sustainable Disease Management. Front. Plant Sci. 2018, 9, 1468. [CrossRef] [PubMed]

2. Ploetz, R.; Freeman, S.; Konkol, J.; Al-Abed, A.; Naser, Z.; Shalan, K.; Barakat, R.; Israeli, Y. Tropical race 4 of Panama disease in the Middle East. Phytoparasitica 2015, 43, 283-293. [CrossRef]

3. Ploetz, R.C. Fusarium Wilt of Banana. Phytopathology 2015, 105, 1512-1521. [CrossRef] [PubMed]

4. Ghag, S.B.; Shekhawat, U.K.S.; Ganapathi, T.R. Fusarium wilt of banana: Biology, epidemiology, and management. Int. J. Pest Manag. 2015, 61, 250-263. [CrossRef]

5. Xu, L.B.; Huang, B.Z.; Wei, Y.R. Production and banana R\&D in China. In Advancing Banana and Plantain RED in Asia and the Pacific; Molina, A.B., Eusebio, J.E., Roa, V.N., Van den Bergh, I., Maghuyop, M.A.G., Eds.; INIBAP: Los Baños, CA, USA, 2003; pp. 77-80.

6. Rekah, Y.; Shtienberg, D.; Katan, J. Spatial distribution and temporal development of Fusarium crown and root rot of tomato and pathogen dissemination in field soil. Phytopathology 1999, 89, 831-839. [CrossRef] [PubMed]

7. Warman, N.M.; Aitken, E.A.B. The Movement of Fusarium oxysporum f. sp. cubense (Sub-Tropical Race 4) in Susceptible Cultivars of Banana. Front. Plant Sci. 2018, 9, 1748. [CrossRef] [PubMed]

8. Biosecurity of Queensland. Panama Disease Tropical Race 4: Biosecurity Standards and Guidelines; Australian Government: Canberra, Australia, 2016.

9. Meldrum, R.A.; Daly, A.M.; Tran-Nguyen, L.T.T.; Aitken, E.A.B. Are banana weevil borers a vector in spreading Fusarium oxysporum f. sp. cubense tropical race 4 in banana plantations? Australas. Plant Pathol. 2013, 42, 543-549. [CrossRef]

10. Sánchez, C.G.; Tixier, P.; Fernández, A.T.; Barboza, A.M.C.; Fernández, J.A.S.; de Lapeyre de Bellaire, L. Can the banana weevil Cosmopolites sordidus be a vector of Fusarium oxysporum f. sp. cubense race 1? Unravelling the internal and external acquisition of effective inoculum. Pest Manag. Sci. 2021, 1, 1-35.

11. Gold, C.S.; Pena, J.E.; Karamura, E.B. Biology and integrated pest management for the banana weevil Cosmopolites sordidus. Integr. Pest Manag. Rev. 2001, 6, 79-155. [CrossRef]

12. Fancelli, M.; Borges, A.L.; Ritzinger, C.H.S.P.; dos Santos Silva, D.; Ringenberg, R. Metamasius hemipterus L. como praga de bananeiras cv. Terra. Rev. Bras. Frutic. 2012, 34, 944-946. [CrossRef]

13. Smith, D. Banana weevil borer control in south-eastern Queensland. Aust. J. Exp. Agric. 1995, 35, 1162-1172. [CrossRef]

14. Tinzaara, W.; Emudong, P.; Nankinga, C.; Tushemereirwe, W.; Kagezi, G.; Gold, C.S.; Dicke, M.; Van, H.A.; Karamura, E. Enhancing dissemination of Beauveria bassiana with host plant base incision trap for the management of the banana weevil Cosmopolites sordidus. Afr. J. Agric. Res. 2015, 10, 3878-3884. [CrossRef]

15. Mora, L.S.; Calvache, H.H.; Avila, M. Diseminación de Rhadinaphelenchus cocophilus (Cobb) Goodey: Agente causal del anillo rojo-hoja corta de la palma de aceite en San Carlos de Guaroa (Meta). Rev. Palmas 1994, 15, 15-27.

16. Hagley, E.A.C. The Role of the Palm Weevil, Rhynchophorus palmarum, as a Vector of Red Ring Disease of Coconuts. I. Results of Preliminary Investigations. J. Econ. Entomol. 1963, 56, 375-380. [CrossRef]

17. Plata-Rueda, A.; Martínez, L.C.; Fernandes, F.L.; de Sousa Ramalho, F.; Zanuncio, J.C.; Serrão, J.E. Interactions between the Bud Rot Disease of Oil Palm and Rhynchophorus palmarum (Coleoptera: Curculionidae). J. Econ. Entomol. 2016, 109, 962-965. [CrossRef]

18. Carvalho, R.R.C.; Warwick, D.R.N.; Souza, P.E.; Carvalho, F.S. Longevidade de Thielaviopsis paradoxa, agente causal da resinose do coqueiro em Rhynchophorus palmarum. Sci. Plena 2011, 7, 1-6.

19. Kassambara, A. Rstatix: Pipe-Friendly Framework for Basic Statistical Tests. R Package Version 0.7.0. 2021. Available online: https:/ /CRAN.R-project.org/package=rstatix (accessed on 15 April 2021).

20. R Core Team. R: A Language and Environment for Statistical Computing. 2018. Available online: https://www.R-project.org/ (accessed on 15 April 2021).

21. Leslie, J.F.; Summerell, B.A. The Fusarium Laboratory Manual; John Wiley \& Sons: New York, NY, USA, 2006.

22. O'Donnell, K.; Kistler, H.C.; Cigelnik, E.; Ploetz, R.C. Multiple evolutionary origins of the fungus causing Panama disease of banana: Concordant evidence from nuclear and mitochondrial gene genealogies. Proc. Natl. Acad. Sci. USA 1998, 95, 2044-2049. [CrossRef]

23. Elzhov, T.V.; Mullen, K.M.; Spiess, A.-N.; Bolker, B. R Interface to the Levenberg-Marquardt Nonlinear Least-Squares; CRAN, 2016.

24. Laird, N.M.; Ware, J.H. Random-effects models for longitudinal data. Biometrics 1982, 38, 963-974. [CrossRef]

25. Pinheiro, J.; Bates, D.; DebRoy, S.; Sarkar, D. NLME Package: Linear and Nonlinear Mixed Effects Models; CRAN, 2018.

26. Baddeley, A.; Turner, R. Spatstat: An R package for analyzing spatial point patterns. J. Stat. Softw. 2005, 12, 1-42. [CrossRef]

27. Gigot, C. Epiphy: Analysis of Plant Disease Epidemics. CRAN. 2018. Available online: https://github.com/chgigot/epiphy (accessed on 15 April 2021).

28. Li, B.; Madden, L.V.; Xu, X. Spatial analysis by distance indices: An alternative local clustering index for studying spatial patterns. Methods Ecol. Evol. 2012, 3, 368-377. [CrossRef]

29. Madden, L.V.; Hughes, G. Plant Disease Incidence: Distributions, Heterogeneity, and Temporal Analysis. Annu. Rev. Phytopathol. 1995, 33, 529-564. [CrossRef]

30. Kaaya, G.P.; Seshu-Reddy, K.V.; Kokwaro, E.D.; Munyinyi, D.M. Pathogenicity of Beauveria bassiana, Metarhizium anisopliae and Serratia marcescens to the banana weevil Cosmopolites sordidus. Biocontrol Sci. Technol. 1993, 3, 177-187. [CrossRef] 
31. Fancelli, M.; Dias, A.B.; Delalibera Júnior, I.; Jesus, S.C.; Nascimento, A.S.; Silva, S.O.E.; Caldas, R.C.; Ledo, C.A.S. Beauveria bassiana strains for biological control of Cosmopolites sordidus (Germ.) (Coleoptera: Curculionidae) in plantain. Biomed. Res. Int. 2013, 13, 184756.

32. Akello, J.; Dubois, T.; Coyne, D.; Kyamanywa, S. Endophytic Beauveria bassiana in banana (Musa spp.) reduces banana weevil (Cosmopolites sordidus) fitness and damage. Crop Prot. 2008, 27, 1437-1441. [CrossRef]

33. Pauli, G.; Lopes, R.B.; Alves, S.B.; Damatto Junior, E.R.; Mascarin, G.M. Falsa broca aumenta a disseminação de Beauveria bassiana em populações de campo da broca-do-rizoma da bananeira. Ciência Rural 2011, 41, 1867-1870. [CrossRef]

34. Mesquita, A.L.M.; Lucchini, F.; Alves, E.J.; Caldas, R.C. Influência dos fatores ambientais no grau de parasitismo de Beauveria bassiana sobre Cosmopolites sordidus e Metamasius hemipterus, em cultivo da bananeira. Pesquisa Andamento 1981, 14, 4.

35. Dolinski, C.; Lacey, L.A. Microbial control of arthropod pests of tropical tree fruits. Neotrop. Entomol. 2007, 36, 161-179. [CrossRef]

36. Karangwa, P.; Blomme, G.; Beed, F.; Niyongere, C.; Viljoen, A. The distribution and incidence of banana Fusarium wilt in subsistence farming systems in east and central Africa. Crop Prot. 2016, 84, 132-140. [CrossRef]

37. Hermanto, C.; Sutanto, A.; Edison, H.S.; Daniells, J.W.; Sinohin, V.; Molina, A.; Taylor, P. Incidence and Distribution of Fusarium Wilt Disease of Banana in Indonesia. Acta Hortic. 2011, 897, 313-322. [CrossRef]

38. Parlevliet, J.E. Components of resistance that reduce the rate of epidemic development. Annu. Rev. Phytopathol. 1979, 17, 203-222. [CrossRef]

39. Carvalho, R.R.C.; de Souza, P.E.; Warwick, D.R.N.; Pozza, E.A.; de Carvalho Filho, J.L.S. Spatial and temporal analysis of stem bleeding disease in coconut palm in the state of Sergipe, Brazil. Ann. Acad. Bras. Cienc. 2013, 85, 1567-1576. [CrossRef] [PubMed]

40. Molet, T. CPHST Pest Datasheet for Metamasius hemipterus; USDA-APHIS-PPQ-CPHST: 2013. Available online: http:// download.ceris.purdue.edu/file/2231 (accessed on 22 March 2019). 